\title{
THE DEVELOPMENT OF TAMAN PENJUMLAHANLEARNING MEDIA ASSESTED ARTICULATE STORYLINE 3 ON ADDITIONAL CONCEPT IN FIRST GRADE OF ELEMENTARY SCHOOL
}

\author{
Anggit Septiani ${ }^{*}$, Meiliana Nurfitriani ${ }^{2}$, Yopa Taufik Saleh ${ }^{3}$ \\ 1,2,3 Pendidikan Guru Sekolah Dasar Universitas Muhammadiyah Tasikmalaya, Indonesia \\ ${ }_{1 *}$ anggitseptiani63@gmail.com \\ 2 meiliana.nurfitriani@umtas.ac.id \\ ${ }^{3}$ Yopa.taufik@umtas.ac.id
}

\begin{tabular}{|c|c|}
\hline Article History & Abstract \\
\hline $\begin{array}{l}\text { Historical Articles } \\
\text { Submitted: 2021-04-03 } \\
\text { Revised: 2021-06-15 } \\
\text { Issued: 2021-06-17 }\end{array}$ & $\begin{array}{l}\text { This study aims to develop and test the effectiveness of the additional media } \\
\text { with the aid of articulate storyline } 3 \text { on the concept of summation in the first } \\
\text { grade of SDN II Linggasirna. The method used is the method of developing } \\
\text { R\&D (Research and Development) Sugiyono. The product trial in this study } \\
\text { includes three stages, namely one-on-one trials conducted on } 3 \text { students, small } \\
\text { group trials conducted on } 7 \text { students, and large group trials conducted on } 20 \\
\text { students. The data analysis technique used in this research is qualitative and } \\
\text { quantitative data analysis. Data collection techniques using a questionnaire and } \\
\text { pretest-posttest. The results of the studv show that the development of the }\end{array}$ \\
\hline $\begin{array}{l}\text { Keywords: } \\
\text { Taman Penjumlahan } \\
\text { Learning Media, } \\
\text { Articulate Storyline, } \\
\text { Concept }\end{array}$ & $\begin{array}{l}\text { addition garden media with the help of articulate storyline } 3 \text { on the concept of } \\
\text { addition is already valid. The results of the pretest and posttest were calculated } \\
\text { using the paired sample T-Test analysis technique, the results obtained were } \\
\text { count }>\text { table or } 12,665>2,093 \text {, which means Ho is rejected and Ha is } \\
\text { accepted, meaning that there is a significant difference between before and after } \\
\text { being given treatment using the media garden summation assisted by articulate } \\
\text { storyline } 3 \text { on the concept of summation in the first grade of SDN II } \\
\text { Linggasirna. Based on the average results, the posttest value of } 87.30 \text { is greater } \\
\text { than the pretest of } 66.05 \text {. Then the addition garden learning media assisted by } \\
\text { articulate storyline } 3 \text { can be said to be feasible and effective to use in the } \\
\text { concept of addition. }\end{array}$ \\
\hline
\end{tabular}

\section{INTRODUCTION}

Mathematics is a universal science that underlies the development of modern technology now. Not only that, the application of mathematics is needed in everyday human life. Therefore, mathematics is a compulsory subject since primary school. However, until now there are still many students who feel that learning mathematics is very difficult, unpleasant and even a frightening specter. The mathematics learning process carried out in elementary schools tends to focus on mastery of memorization, the learning process is teacher-centered (teacher centered) by relying on learning materials from available mathematics resource books, the method used is dominated by the lecture method, and there are no teaching aids used. used so that students are not involved and even tend to be passive (Magnatis, 2019; Tinah, 2019) . The ability of the concept of the count operations to add whole numbers to primary school students in first grade is still not optimal (Karlimah et al., 2019). The findings from the research results about student errors in using place values are important information for teachers, so they become evaluation materials for the learning process. Mathematic is indeed a difficult subject, but everyone should learn it because it is closely related to everyday life (Sundayana, 2016). Abstract mathematical objects are one of the obstacles for students' difficulties in understanding mathematics material. Furthermore, 
teachers often have difficulty delivering math material. This causes students to not reach the Minimum Completeness Criteria (KKM) (Ishak, 2019).

In this kind of condition, the teacher should not ignore the role of learning media. It must be admitted that learning media has a positive contribution in helping students to understand mathematics material that is abstract into concrete. There are many media that can help in the learning process such as images, audio, video and multimedia. Currently, ICT-based media is indeed an issue in the world of education. This is also explained in (Hidayatullah et al., 2011) suggesting that the National Training Program For Teacher Educators On ICT-Pedagogy Integration workshop held by APEID, UNESCO and SEAMEOLEC in 2006 in Jakarta indicates the importance of integrating ICT/ICT skills with skills teaching in order to create effective, innovative and fun learning. The importance of using ICT in mathematical literacy was also conveyed in PRISMA, (the 2018 national mathematics seminar proceedings) explained that the use of ICT in mathematical literacy is very important in accordance with the objectives of mathematical literacy, namely analyzing, solving and interpreting problems in everyday life. That is, the use of media in mathematics is important because it can help students understand the material in learning. Besides that, it can also motivate to learn the next material. Because mathematics material is interrelated, such as understanding multiplication, students must understand addition.

According to an interview in February 2020 with Mrs. Yati Nurhayati, S.Pd.SD as a hometeacher of grade I at SDN II Linggasirna, there were several obstacles in learning math the concept of addition. The obstacle is that students do not understand the concept of addition. In addition, students 'interest in learning summation material is felt to be lacking because there are students' responses to learning that are active and some are only paying attention. In the learning process of addition material, the teacher only uses imageaided media such as number cards. If the problem is not resolved immediately, it will affect student achievement. Anticipating these obstacles, the authors are interested in developing learning media that is attractive, stimulates students to actively learn and has fun. Taman Penjumlaban learning media assisted by articulate storyline 3 can potentially help students to understand the concept of addition, because one of the features from this media were presentation and conveying information. Furthermore, ariculate storyline 3 also provides a flash feature in making animation but has a simple appearance like a power point. In addition, there are also various kinds of templates that can be used to create interactive media, especially for making practice questions and test questions. The learning media produced by the articulate storyline 3 software in this study is included in the audio-visual media type. In this study, the researcher will develop a Taman Penjumlaban learning media to supported mathematics learning. Therefore, the researchers focused their research on developing of Taman Penjumlaban learning media learning media assisted by articulate storyline 3 on the concept of addition in first grade SDN II Linggasirna.

\section{METHOD}

This research is a research and development. This development research is aimed at producing mathematics learning media, namely Taman Penjumlaban. This research was conducted in the first grade of SDN II Linggasirna, Tasikmalaya. The R\&D research method is a research method used to produce certain products and test the effectiveness of these products (Sugiyono, 2016). This research development procedure adapted Sugiyono's type of development. The researcher modified the research and development steps according to Sugiyono which consisted of: potential and problem stages, data collection stage, product design stage, validation stage, product revision stage, trial stage, and final product revision stage so that it became a garden media product of the summation. can be used in the learning process.

The data analysis techniques used in this study were quantitative data analysis techniques and qualitative data analysis. Data in the form of suggestions from experts, 
teachers and students during the trial process will be analyzed descriptively qualitatively. Data in the form of scores of responses from media experts, material experts, teachers, and students obtained through a questionnaire will be analyzed descriptively quantitatively with percentage and categorization techniques. The conversion of qualitative to quantitative data uses a scale of five. The conversion uses the Widoyoko formula in (Nurlela, 2019). Table 1 presents the conversion of quantitative qualitative data. The following is described in more detail in the table below:

Table 1 Conversion of quantitative o qualitative Data

\begin{tabular}{ccc}
\hline Interval & Interval & Criteria \\
\hline$x>\bar{x}+1.8 s b i$ & $x>4.21 x$ & Very Good \\
$\overline{x_{l}}+0.6 s b i<x<\bar{x}_{l}+1.8 s b i$ & $3.40<x \leq 4.21$ & Good \\
$\bar{x}_{l}+0.6 s b i<x<\bar{x}_{l}+0.6 s b i$ & $2.60<x \leq 3.40$ & Enough \\
$\bar{x}_{l}+1.8 s b i<x<\bar{x}_{l}+0.6 s b i$ & $1.79<x \leq 2.60$ & Less \\
$x>\bar{x}_{l}+1.8 s b i$ & $x \leq 1.79$ & Very Less \\
\hline
\end{tabular}

where:

$x_{i} \quad:$ Average

$: 1 / 2$ (ideal maximum score + ideal minimum score)

sbi : Ideal standar deviation

$: 1 / 6$ (ideal maximum score + ideal minimum score)

$x \quad$ : Empirical score

The pretest and posttest results were analyzed descriptively quantitatively. To determine the effectiveness of the media, namely using the statistical N-Gain test and Paired Sample T-test. The N-Gain test and Paired Sample T-test were used to determine the level of effectiveness of the learning media and the significance of learning differences in the summation concept material in first grade of SDN II Linggasirna between before and after being treated in the form of using the Taman Penjumlahan media of addition by conducting pretest and posttest on the conceptual material addition. The N-Gain test formula according to Melter (in Nurlela 2019: 69) which is used for the pretest and posttest calculations is calculated using Eq.(1).

$N-$ Gain $=\frac{\text { Posttest score }- \text { pretest score }}{\text { maximum score-pretest score }}$

Then, Table 2 present the criteria of normalized gain score.

Table 2 Normalized Gain Score Criteria

\begin{tabular}{cc}
\hline Gain score & Interpretation \\
\hline$g>0.7$ & High \\
\hline $0.3<g \leq 0.7$ & Medium \\
\hline$g \leq 0.3$ & Low \\
\hline
\end{tabular}

While the Paired Sample t-test formula according to Sabana (in Nurlela 2019: 70) which is used for the pretest and posttest calculations is calculated using Eq. (2)

$$
t=\frac{M d}{\sqrt{\frac{\sum d^{2-\frac{\sum d^{2}}{n}}}{n(n-1)}}}
$$

where: 
$M d$ : Average from gain between posttest \& pretest

$d:$ Gain score test to posttest score every subject

$n$ : number of subject

To find out the difference in effectiveness between before and after using the Taman Penjumlahan learning media, the hypothesis are shown below.

$\mathrm{H}_{0}$ : There is no significant difference between before and after using the Taman Penjumlahan learning media assisted by articulate theoryline 3 on the addition concept in first grade of SDN II Linggasirna.

$\mathrm{H}_{\mathrm{a}}$ : There is a significant difference between before and after using the Taman Penjumlahan learning media assisted by articulate theoryline 3 on the addition concept in first grade of SDN II Linggasirna.

If $\mathrm{t}_{\text {count }}<\mathrm{t}_{\text {table }}$ then $\mathrm{H}_{0}$ is accepted and $\mathrm{H}_{\mathrm{a}}$ is rejected at sig. 0.05 .

If $\mathrm{t}_{\text {count }}>\mathrm{t}_{\text {table }}$ then $\mathrm{H}_{0}$ is rejected and $\mathrm{H}_{\mathrm{a}}$ is accepted at sig. 0.05 .

\section{RESULTS}

The product of the development is Taman Penjumlaban learning media assisted by articulate storyline 3 on the concept of addition. Taman Penjumlahan learning media is learning media in the form of an application that is used through personal computers.

\section{a. Potentials and Problem}

In the first step, namely the potential and problems. Based on the results of interviews with first grade teacher at SDN II Lingasirna, namely Mrs. Yati Nurhayati, S.Pd.SD, there are problems in mathematics subjects regarding the concept of addition in first grade including the following: students do not understand the material of the concept of addition; the media used when learning the concept of addition only uses makeshift media, namely pictures; some students have not reached the KKM score set in mathematics subject matter the concept of addition; Student responses when learning is taking place, some are active to take part in learning and some are passive because they do not understand the material presented.

Based on some of the problems encountered in the field, the authors are interested in developing learning media that are attractive to students, can create a pleasant learning atmosphere and help students' interest in learning to be more active in following the learning process. Taman Penjumlahan learning media can also help students to more easily understand the concept of addition material.

\section{b. Data collection}

To solve this problem, the researcher developing a Taman Penjumlaban learning media. In developing the Taman Penjumlahan media, the researchers obtained information about the media used in the addition concept as reference material. The media are papan planel penjumlahan and tangga pintar leraning media. In addition, researchers also obtained information about the curriculum used to find basic competencies that are suitable for the development of Taman Penjumlahan media. The basic competencies used are KD 3.3 explaining and doing addition and subtraction of numbers involving whole numbers up to 99 in everyday life and $\mathrm{KD} 4.3$ solving problems of everyday life related to addition and subtraction of numbers involving whole numbers up to 99 .

\section{c. Product Design}

At the product design step of this study, namely by making a story board and flowchart. The Story Board of the Taman Penjumlahan learning media is a more detailed sketch / design of the Taman Penjumlahan learning media application that will be developed, thus forming a picture of the application that will be produced. While the flowchart of Taman Penjumlaban 
learning media is a model of the flow of thinking applications from several files on the learning media for the garden of addition.

\section{d. Design Validation}

In the validation design step of the Taman Penjumlahan learning media is validation process. Validators involved at this step are material experts, media experts and teachers. Media validation, namely by Mohammad Fahmi Nugraha, M.Pd as a lecturer in the Primary School Teacher Education Study Program, Muhammadiyah University of Tasikmalaya. The validation of the material was by Milah Nurkamilah, M.Pd as a mathematics lecturer in the Information Technology Education Study Program, Muhammadiyah University of Tasikmalaya. Teacher validation was by Yati Nurhayati, S.Pd.SD as a first grsde teacher at SDN I Linggasirna. The results of the material expert's validation on the Taman Penjumlaban media summation are presented in the Figure 1.

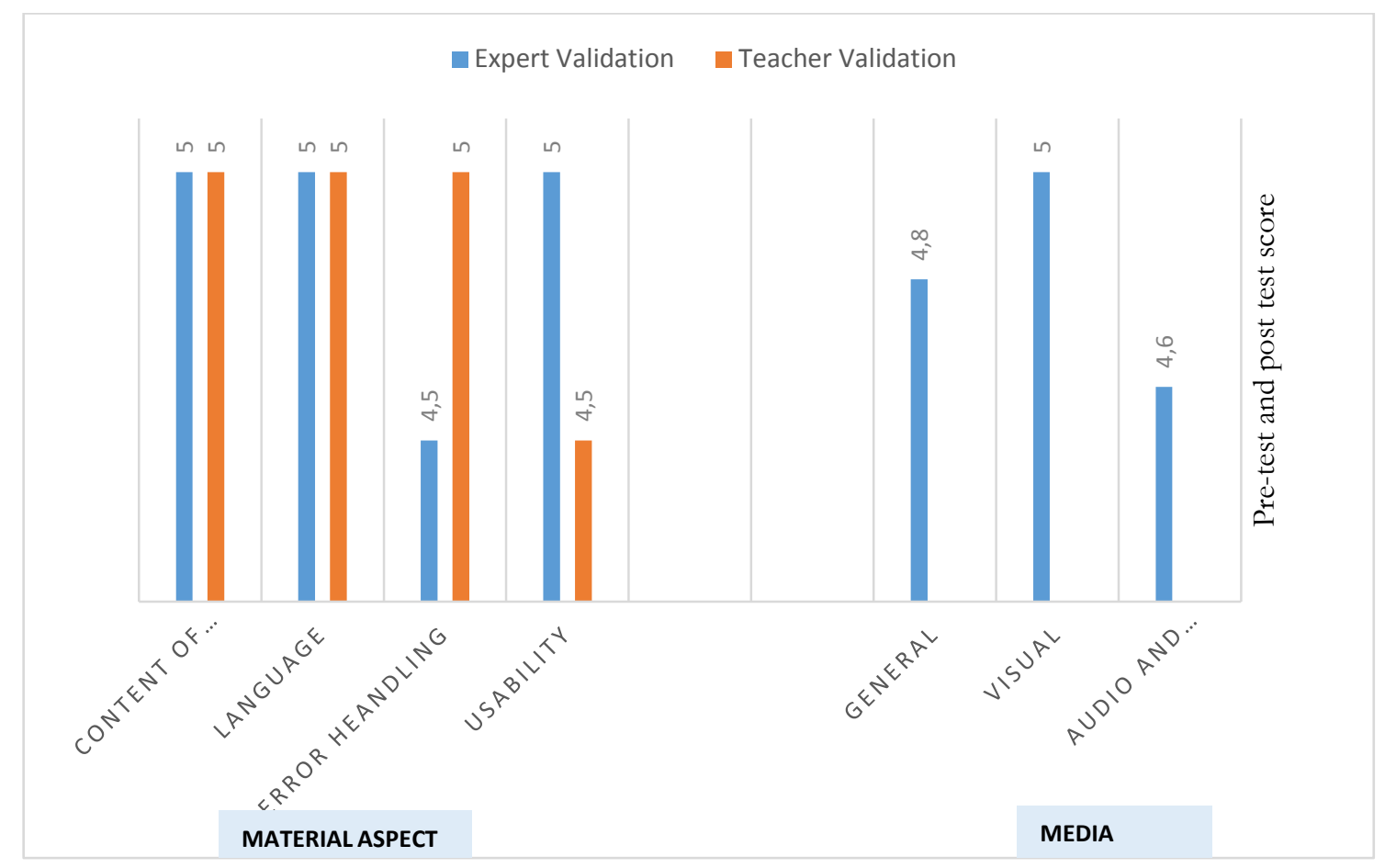

Figure 1 Recapitulation of The Result of Material and Media Aspect V alidation

Based on Figure 1, the results of the validation of the material from expert validation obtained an average score of 4.90 in the "very good" category. the results of the validation of the teacher obtained an average score of 4.90 in the "very good" category, so that the Taman Penjumlahan learning media assisted by articulate storyline 3 were declared feasible to be tested. Furthermore, based so that the Taman Penjumlahan learning media assisted by articulate storyline 3 were declared feasible to be tested. The next validation, namely the validation of media experts on the Taman Penjumlaban media is presented in the following Table 3:

Table 3 Racapitulation of The Results of Media Experts Validation

\begin{tabular}{clccc}
\hline No & \multicolumn{1}{c}{ Aspect } & Aspect Value & Average score & Category \\
\hline 1. & General & 24 & 4.80 & Very good \\
2. & Visual & 35 & 5.00 & Very good \\
3. & Audio and Language & 14 & 4.60 & Very good \\
\hline \multicolumn{2}{r}{ Total } & $\mathbf{7 3}$ & $\mathbf{4 . 8 0}$ & Very good \\
\hline
\end{tabular}


Based on tabel 3, the results of the media expert's validation obtained an average score of 4.80 in the "very good" category, so the Taman Penjumlahan learning media assisted by articulate storyline 3 were declared feasible to be tested.

\section{e. Product Revisions}

At this step, Taman Penjumlahan learning media assisted by articulate storyline 3 were revised based on the results of validation by material experts and media experts. Inputs of improvement from media experts are as follows:

1). The voice of Lala's character in the material menu must use the voice of the researcher. Initially, the voice of Lala's character in the material menu was dubbed using the google engine voice.

2). In the material menu, a back button must be added to the main menu. The material menu before revision and after revision are presented in Figure 2 and Figure 3.

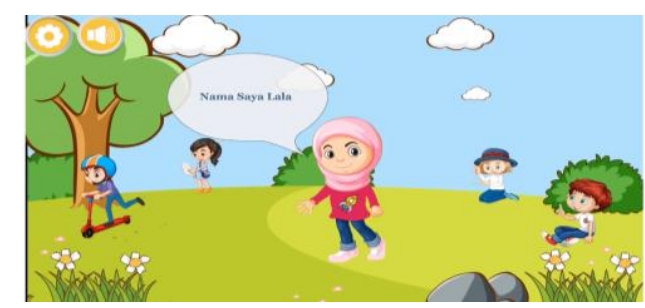

Figure 2 material menu display before revision

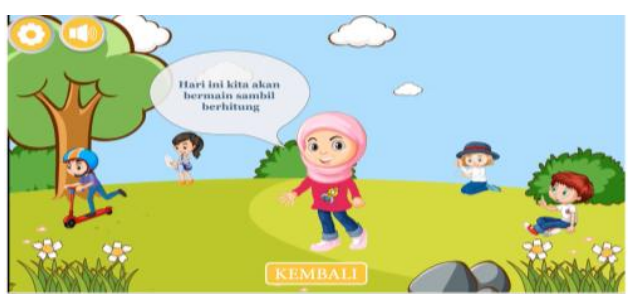

Figure 3 material menu display after revision

3). In the game menu display, the player name input field must be added. The following is the appearance of the game menu before revision and after revision are presented in Figure 4 and Figure 5:

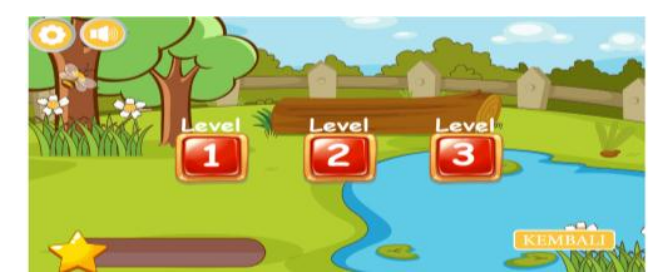

Figure 4 Game Menu Display Before Revision

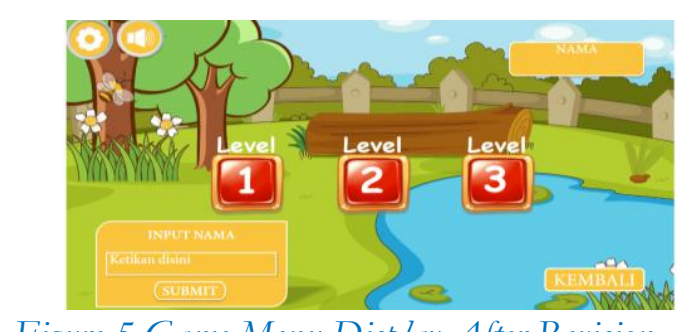

Figure 5 Game Menu Display After Revision

While the corrective input from the material expert is as follows: 
1). In the game menu, before the revision of the game concept, if you can't answer the questions, the game cannot be continued. After the revision there are suggestions from material experts, namely the concept of the game being one time answer can be continued to the next question.

2). In the learning objectives menu, students' basic competencies must be added.

3). On the menu the material must be made into three items. The following is a look at the material menu before and after a revision are presented in Figure 6 and Figure 7:

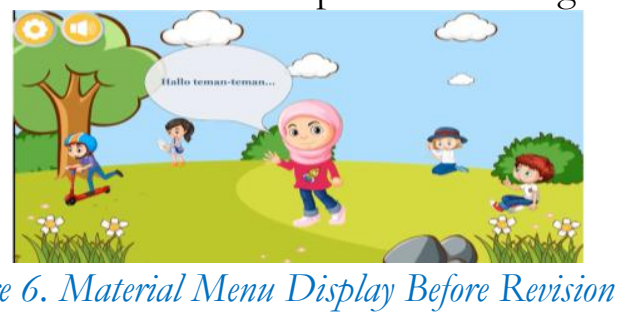

Figure 6. Material Menu Display Before Revision

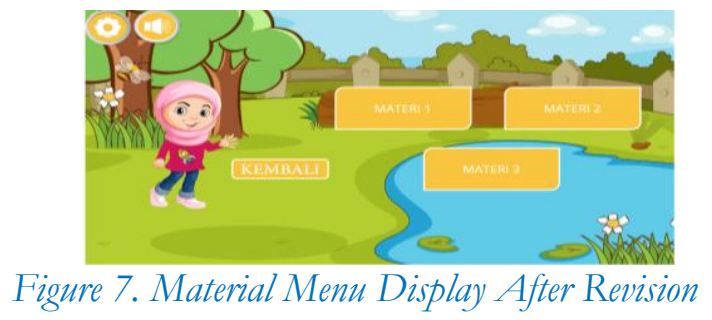

\section{f. Trial}

At this step, after the taman penumlahan learning media assisted by articulate storyline 3 were validated and revised, then the product was tested. Before testing the product, all first grade students of SDN II Linggasirna were given pretest questions to measure the students' initial abilities. Then at the end of the product trial, a posttest question was given to measure the students' ability after being given action using the garden media of addition assisted by articulate storyline 3 .

In the first step, a one-on-one trial was carried out on three first grade students of SDN Padarame which then carried out product analysis and revision. Furthermore, in the second step, small group trials were carried out. The trial was carried out on seven second grade students of SDN Padarame. The following is a recapitulation of the results of the one-to-one and small-group trials are presented in Table 4:

Figure 4 Recapitulation Results of The One-to-One and Small-Group Trials

\begin{tabular}{llccc}
\hline No & \multicolumn{1}{c}{ Aspect } & \multicolumn{2}{c}{ Total Score Trials } & Category \\
& & One-to-one & Small Group & \\
\hline 1. & Ease of understanding & 29 & 69 & Very good \\
2. & Interest Learning & 43 & 100 & Very good \\
3. & Usability & 43 & 98 & Very good \\
4. & Visual \& Language & 29 & 69 & Very good \\
\hline \multicolumn{2}{l}{ Average score } & $\mathbf{4 , 8 0}$ & $\mathbf{4 , 8 0}$ & Very good \\
\hline
\end{tabular}

Based on the results of the one-one trial data analysis, the overall score was 4.80 in the "very good" category. This means that the garden of summation media is suitable for use and there is no revision. Meanwhile, based on the results of the small group trial data analysis, the overall score was 4.80 in the "very good" category. This means that the garden of summation media is suitable for use and there is no revision. 
In the large group trial, a pretest was carried out on 20 first grade students of SDN II Linggasirna followed by data analysis and product revision. At this step, learning was carried out in three meetings with a duration of $2 \times 35$ minutes. After the large group test the third meeting was finished, then the posttest was carried out. Posttest aims to determine the ability of students after being given the action three times using the garden media of addition assisted by articulate storiline 3. To determine the effectiveness of the media, namely using the statistical N-Gain test and Paired Sample T-test. The result of large group trial is presented in Table 5.

Figure 5 Recapitulation of $V$ alue and Level of Media Effectiveness

\begin{tabular}{ccccc}
\hline Students & $\begin{array}{c}\text { Pretest } \\
\text { average }\end{array}$ & $\begin{array}{c}\text { Posttest } \\
\text { average }\end{array}$ & $\begin{array}{c}\text { Normal } \\
\text { gain }\end{array}$ & Category \\
\hline 20 & 66,05 & 87,30 & 0,59 & Medium \\
\hline
\end{tabular}

Based on the table above, it shows that the pretest average value is 66.05 and the posttest average score is 87.30 . This means that the posttest value is higher than the prettest value. Furthermore, the quality level of media effectiveness is 0.59 with the "medium" category. Furthermore, the pretest-posttest value data will be analyzed by using the Paired Sample T-Test with a significance level of 0.05. The results of the Paired Sample T-Test analysis is presented Table 6.

Figure 6 Results of Paired Sample t-tes

\begin{tabular}{|c|c|c|c|c|c|c|c|c|}
\hline & \multicolumn{5}{|c|}{ Paired Differences } & $\mathrm{T}$ & Df & $\begin{array}{l}\text { Sig. }(2- \\
\text { tailed) }\end{array}$ \\
\hline & \multirow[b]{2}{*}{ Mean } & \multirow{2}{*}{$\begin{array}{c}\text { Std. } \\
\text { Deviatio } \\
\mathrm{n}\end{array}$} & \multirow{2}{*}{$\begin{array}{l}\text { Std. } \\
\text { Error } \\
\text { Mean }\end{array}$} & \multicolumn{2}{|c|}{$\begin{array}{l}95 \% \text { Confidence } \\
\text { Interval of the } \\
\text { Difference }\end{array}$} & & & \\
\hline & & & & Lower & Upper & & & \\
\hline $\begin{array}{ll}\text { Pair } 1 & \text { pretest - } \\
& \text { posttest } \\
\end{array}$ & $-21,250$ & 7,504 & 1,678 & $-24,762$ & $-17,738$ & $-12,665$ & 19 & ,000 \\
\hline
\end{tabular}

Based on the table data above, it shows that tcount is 12.665 with $\mathrm{df} 19$, so that $\mathrm{t}$ table is 2.093 with a significance of 0.05 , then $t_{\text {count }}>t_{\text {table }}$ is $12.665>2.093$, thus it can be concluded that $\mathrm{H}_{0}$ is rejected and $\mathrm{H}_{2}$ is accepted. This means that there is a significant difference between before and after using Taman Penjumlahan learning media assisted by articulate storyline 3 on the addition concept in first grade of SDN II Linggasirna. Furthermore, based on the posttest average score of 87.30 , it has met the minimum passing criterion (KKM) value in mathematics, which is 72 . The average posttest score is greater than the average prestest score of 87.30> 66.05. So the Taman Penjumlahan learning media assisted by articulate storyline 3 are said to be feasible and effective to be used in learning addition concept material.

\section{g. Final Product Revision}

Product revisions are carried out if there are suggestions and input based on the results of one-on-one trials, small group trials and large group trials. Based on the results of one-on-one trial data, small group trials and large group trials in this study, there were no suggestions and suggestions for improvement.

\section{DISCUSSION}


Taman Penjumlahan learning media is a learning medium that serves to assist teachers in delivering the addition concept material. In addition, the Taman Penjumlaban learning media also helps students to understand the material in an easy and fun way so that student motivation in learning mathematics is spurred. The Taman Penjumlahan learning media are assisted by articulate storyline 3, which is a type of audio-visual media. This media is in the form of an application in which there are several menus and voice guides. In this media, there is a material menu containing interactive videos on the concept of addition. The video contains the storyline of the little girl who is walking around the park then added the events that require the player to calculate the sum interactively. In addition, this media also has a game menu. The game menu contains several addition concept questions with certain levels. Taman Penjumlahan media has several advantages, including the following: (1) this media can be downloaded and stored on a personal computer making it easier for students to use this media anywhere; (2) the Taman Penjumlahan media including the type of audiovisual media. So that it can stimulate student interest in learning. In addition, the color design that is adjusted to elementary school age children can affect the child's memory of the material presented in the long term; (3) The Taman Penjumlaban learning media is also equipped with a menu of material in the form of animated videos. So that it can make it easier for students to understand the concept of addition according to everyday life; (4) The Taman Penjumlahan learning media is also equipped with a game menu. This game menu consists of several questions that serve to hone students' abilities in the concept of addition.

Reviewed from the features developed in this study, it has an impact on increasing students' understanding of concepts. This can be seen from the results of the analysis using paired sample t-test, it is known that there are significant differences and improvements in cognitive learning outcomes. These results prove that the superior audio-visual features in this media can be useful for learning mathematics. Articulate Storyline media is proven to increase students' interest in learning through learning activities and can be used as a supporting medium for teachers in delivering learning materials (Oktaviana et al., 2020; Sari \& Harjono, 2021). Besides being able to be used as a learning medium for addition material in lower grades, it can also be used for some characteristics of mathematics learning materials such as algebra and function graphs (Nissa et al., 2021; Pratama, 2019).

The results showed that the Taman Penjumlahan lerning media assisted by articulate storyline 3 was valid. Validation was carried out by media experts with an average score of 4.80 for very good categories, material experts with an average score of 4.90 for very good categories, and teachers with an average score of 4.90 for very good categories. The test results obtained an average score of 4.80 for very good categories and the results of the small group test obtained an average score of 4.80 for the very good category. Based on the average result, the postest score of 87.30 was greater than the pretest score of 66.05. So Taman Penjumlahan learning media assisted by articulate storyline 3 can be said to be feasible and effective to use in the concept of addition.

The results of this study are in line with those expressed by (Erviana \& Muslimah, 2018; Matsuo et al., 2008) that learning using media can increase learning motivation and make learning more interesting. Media developed according to students level of thinking will improve learning outcomes. Based on the results of this study and several relevant studies, it is known that the importance of media in supporting the learning process. Other research that proves that mathematics also requires media in learning either visually or in the form of teaching aids as a learning tool, such as the Dakota game in learning. Based on the results of the study, it was known that there was an increase in learning mathematics before and after being given treatment (Rahmawati et al., 2020).

\section{CONCLUSION}


According to the result and discussion, it can be concluded that this research and development has already produce Taman Penjumlaban learning media assisted by articulate storyline 3. This type of development research used the Sugiyono adaptation model. Taman Penjumlahan learning media assisted by articulate storyline 3 is stated to be used in learning mathematics on the concept of addition. This is based on the assessment of media experts, material experts and classroom teachers.

Assessment by media experts got a score of 4.80 in the very good category; The assessment by the material expert got a score of 4.90 in the very good category; The assessment by the teacher got a score of 4.90 in the very good category. The results of the one-on-one trial got an average score of 4.80 with the very good category and the small group trial got an average score of 4.80 with the very good category. In the large group test, the level of effectiveness based on the $\mathrm{N}$-gain test got a score of 0.59 in the moderate category. The results of the pretest and posttest were calculated using the paired sample TTest analysis technique, the results obtained were $t_{\text {count }}>t_{\text {table }}$ or 12.665>2.093, which means that $\mathrm{H}_{0}$ was rejected and $\mathrm{H}_{\mathrm{a}}$ was accepted, meaning that there was a significant difference between before and after being given treatment using Taman Penjumlahan assisted by articulate storyline 3 on the addition concept in first grade of SDN II Linggasirna.'

\section{REFERENCE}

Erviana, V. Y., \& Muslimah. (2018). Development of Learning Media Smart Ladder Addition and Subtraction Material for Class I Elementary School. Jurnal Penelitian Ilmu Pendidikan, 11(1), 58-67.

Hidayatullah, Akbar, \& Rahim, Z. (2011). Educational Animation Using Flash. Informatika.

Ishak. (2019). Efforts to Improve Student Learning Outcomes About the Concept of Reduction Through Bowlingur Games in First Grade of SD Negeri 1 Pangkalpinang. Cendekiawan, 1(1), 7-12. https://doi.org/10.35438/cendekiawan.v1i1.153

Karlimah, K., Nur, L., \& Oktaviyani, H. (2019). Understanding the Concept of Operational Counting Addition of Whole Numbers for Elementary School Students. Premiere Educandum: Jurnal Pendidikan Dasar Dan Pembelajaran, 9(2), 123. https://doi.org/10.25273/pe.v9i2.4887

Magnatis, U. (2019). Efforts to Improve Student Achievement in Class IV Elementary School 7 Sungailiat Mathematics Subjects About Mixed Counting Operations Through Methods Demonstrasi. Cendekiawan, 1(1), 20-28. https://doi.org/10.35438/cendekiawan.v1i1.155

Matsuo, K., Barolli, L., Xhafa, F., Koyama, A., Durresi, A., \& Takizawa, M. (2008). Implementation and design of new functions for a web-based e-learning system to stimulate learners motivation. Proceedings - CISIS 2008: 2nd International Conference on Complex, Intelligent and Software Intensive Systems, 513-518. https://doi.org/10.1109/CISIS.2008.81

Nissa, A. D. A., Toyib, M., Sutarni, S., Akip, E., Kadir, S., Ahmad, \& Solikin, A. (2021). Development of Learning Media Using Android-Based Articulate Storyline Software for Teaching Algebra in Junior High School. Journal of Physics: Conference Series, 1720(1). https://doi.org/10.1088/1742-6596/1720/1/012011

Nurlela, S. K. (2019). Development of Learning Media Kite Numbers on the Place Value Concept of Numbers at SDN 2 Singaparna. Universitas Muhammadiyah Tasikmalaya. 
Oktaviana, S. D., Kristiana, A. I., \& Murtikusuma, R. P. (2020). Development of Interactive Learning Media with Animaker and Articulate Storyline on Permutation and Combination Subject. International Journal of Academic Multidisciplinary Research (IJAMR), $4(1), 30-33$.

Pratama, R. A. (2019). Learning Media Based on Articulate Storyline 2 on Functional Graph Drawing Materials at Patra Dharma 2 Junior High School Balikpapan. Jurnal Dimensi, 7(1), 19-35. https://doi.org/10.33373/dms.v7i1.1631

Rahmawati, F., Permana, R., \& Nurfitriani, M. (2020). The Influence of Dakota Media and Activeness on Student Achievement in. Jurnal Cendekiawan, 2(2), 95-103.

Sari, R. K., \& Harjono, N. (2021). PDevelopment of Articulate Storyline-Based Interactive Learning Media in Science Subjects for Class VII Students. Jurnal Pedagogi Dan Pembelajaran, 4(1), https://ejournal.undiksha.ac.id/index.php/MI/article/view/31555

Sugiyono. (2016). Quantitative, Qualitative and RङD Research Methods. PT Alfabet.

Sundayana, R. H. (2016). Media and Teaching Aids in Mathematics Learning. Alfabeta.

Tinah. (2019). Efforts to Improve Student Activities and Learning Outcomes About Area of Flat Shapes Using Puzbatar Media. Cendekiawan, 1(1), 1-6. https://doi.org/10.35438/cendekiawan.v1i1.152 